\title{
A Discursive Analysis of the Interactive Meaning in Covid-19 Containment Discourses in Social Media: Perspectives on Family Relationships
}

\author{
Margaret Nasambu Barasa ${ }^{1}$, Vicky Inviolata Khasanda ${ }^{2}$, George Nyandoro ${ }^{3}$
}

\author{
${ }^{1}$ Department of Languages, Linguistics and Literature, Kisii University, P.O BOX, 408-40200, Kisii, Kenya \\ ${ }^{2}$ Department of Literary and Communication Studies, Laikipia University, Kenya \\ ${ }^{3}$ Department of Languages, Linguistics and Literature, Kisii University, Kenya
}

\begin{abstract}
Nowadays social media has penetrated into people's daily life playing an important role. Whether through tools such as computers, mobile phones, or other network terminals, social media has become one of the indispensable elements of human society. With information technology rapidly increasing, visual languages become more important in social media. The various semiotic resources such as language, image, better convey the message. Using Critical Discourse Analysis (CDA) and Multimodal Discourse Analysis (MDA) within the Systemic Functional Linguistics (SFL) as its theoretical bases, this study sought to provide insight into the perspective of family relationships as represented in social media in Kenya during the Covid 19 Containment interventions. Specifically, the paper sought to analyse the interactive meaning constructed in linguistic mode, analyse how the interactive meaning facilitated in visual mode and lastly how the linguistic and visual modes combined to construct the interactive meaning. Using theoretical sampling, twenty-eight (28) texts were sampled from the internet and whatsup groups then described, analysed and explained within the CDA and MDA approaches with a view to identify the perspectives on family relationships as expressed in the Covid 19 social media discourses. The findings revealed the following family issues, poverty, strained couple relationships, domestic violence, spouse cheating, spousal mobile phone snooping, constrained family finances, challenges of parenting, couple dominance and power struggle, family unity and issues to do with conjugal right and child bearing.
\end{abstract}

Keywords-CDA, Covid-19, Multimodality, Language, Social media, family perspectives.

\section{INTRODUCTION}

Culture and society are produced through interactions between people, objects and environments. Within these interactions, modes of spoken and written language are some of a diverse range of modes involved in producing meaning and experience. Social media is one of the widest and commonest modes of communication nowadays. Through social media interactions, people share through language on diverse subjects ranging from social, political or economic. Given the fact that social media is not largely restricted, people have the freedom to share even on very emotive and intricate matters in society. Such may include family issues and even politics. This paper focuses on how people interacted on social media on issues pertaining to family relationships during the Covid 19 pandemic in 2020. The Covid 19 pandemic was first reported in China in December, 2019 and since then, it has affected so many people worldwide with several reported deaths. Of particular mention is that his disease spreads through contact with an infected person when you touch the eyes, nose and mouth. Consequently, governments took measures to contain it through measures such as asking people to avoid contact, wear masks and keep social distance to avoid transmission of the disease. One is mitigation: slowing down the spread of the epidemic but not interrupting the transmission completely, while ensuring the healthcare needs for those who are at risk of developing serious forms of the infection are met. This approach, which includes "social distancing" 
along with isolation and quarantining of cases. These were drastic measures because they called for most people to stay at home and also observe hygiene. The measure to stay home had its own impact on the society. The lockdown called for travel restrictions and movements of any sort. Families had to stay together because some had to leave work and rejoin their families. It is against this background that this study explores how the social media was used by people to air out their perspectives on family relationships during the Covid 19 lockdown.

COVID-19 is a disease caused by a new strain of coronavirus. 'CO' stands for corona, 'VI' for virus, and ' $\mathrm{D}$ ' for disease. Formerly, this disease was referred to as '2019 novel coronavirus' or '2019-nCoV.' (ECDC; 2020). The COVID-19 virus is a new virus linked to the same family of viruses as Severe Acute Respiratory Syndrome (SARS) and some types of common cold. Symptoms can include fever, cough and shortness of breath. In more severe cases, infection can cause pneumonia or breathing difficulties. More rarely, the disease can be fatal. These symptoms are similar to the flu (influenza) or the common cold, which are a lot more common than COVID-19. The virus is transmitted through direct contact with respiratory droplets of an infected person (generated through coughing and sneezing). Individuals can also be infected from and touching surfaces contaminated with the virus and touching their face (e.g., eyes, nose, mouth). The COVID-19 virus may survive on surfaces for several hours, but simple disinfectants can kill it (UNICEF, NEWYORK, 2020)

From the time when the first cases of COVID-19 were identified in Wuhan City, China, in December 2019, WHO has been at the forefront of the country's containment efforts. The WHO Country Office in China, supported by the Regional Office for the Western Pacific and global headquarters, has provided the Government of China with technical advice on detection, testing, isolation and quarantine measures to support a rapid response to contain the outbreak (ECDC, 2020)

In summary, as with other respiratory infections like the flu or the common cold, public health measures are critical to slow the spread of illnesses. Public health measures are everyday preventive actions that include: staying home when sick; covering mouth and nose with flexed elbow or tissue when coughing or sneezing. Dispose of used tissue immediately; washing hands often with soap and water; and cleaning frequently touched surfaces and objects. Some of other effective mitigation measures include practicing effective personal and public hygiene, protecting the most vulnerable to the disease and isolating people who are currently infected through self-quarantine and social quarantine (World Health Organization, 2020).

The might be effects of the lockdown are perceived to have a negative impact on the society, both social, economic and political. This paper focuses on the social effects and in particular on family relationships. The following as some of the effects of the lockdown on the social systems in the society". (The Guardian, March 28, 2020). Firstly, they can put the families of informal workers, especially daily laborers, at the risk of starvation, crime, and disease. From South Asia to Africa to Latin America, hundreds of millions of informal workers, without unemployment insurance, paid leave, or savings, would rather work and face the risk of infection than starve (The Wall Street Journal, April 2, 2020). Secondly, they may create the conditions for unbridled domestic violence. Being in close quarters with an abusive spouse or parent is dreadful. It can be even worse when police protection is unavailable as police resources are diverted to enforcing the lockdown. In Hubei province in China, the initial epicenter of the coronavirus outbreak, official reports of domestic violence tripled during the quarantine. "Women and children who live with domestic violence have no escape from their abusers during quarantine, and from Brazil to Germany, Italy to China, activists and survivors say they are already seeing an alarming rise in abuse" (The Guardian, March 28, 2020).

Social media is one of the media that most people use in communication especially those in quarantine and lockdowns. Social media platform is an interactive mode that reaches out to many people within a very short time. Based on this, this study sought to evaluate the perspectives on family relationships as evidenced in social media discourses during the Covid 19 mitigation measures.

\section{THEORETICAL FRAMEWORK}

This study employs Critical Discourse analysis (CDA) (Machin \& Mayr, 2012) and the Multimodal Discourse Analysis (MDA) approach within the Systemic Functional Grammar (SFG) framework (Machin,2007).

Critical Discourse Analysis (CDA) is an approach that views language as a social practice. The foundations of CDA is to study "the way social power abuse, dominance, and inequality are enacted, reproduced, and resisted by text in talk and the social and political context" (including media) 
(van Dijk, 2003, p. 352). Texts are often sites of struggle and usually, brings out ideologies which are subtle. Ideology is a set of interlocking assumptions about some aspect of reality-the "basis of social representations shared by members of a group" (van Dijk, 1998, p. 8, Fairclough, 1989, 1992 , 1995) whereas hegemony is the dominance or influence of one group over another (political, economic, etc.). In addition, ideologies are a set of ideas, not a single idea held by groups, not by individuals and often "naturalized" by language (Janks, 1997). This paper adopts CDA framework to analyse the Covid 19 social media discourse with a view to describing, explaining and interpreting the perspectives held by groups on issues of family relationships. This paper employs CDA within Fairclough's framework to analyse the language used in the texts.

Multimodal Discourse Analysis (MDA) is an approach that looks at multiple modes of communication such as text, colour and images. It is a method of discursive analysis that looks at not just how individual modes communicate but how they interact with one another to create semiotic meaning (Halloran \& Smith, B 2010). Multimodal Discourse Analysis of communication in all its forms, but is particularly concerned with texts which contain the interaction and integration of two or more semiotic resources- or modes of communication-in order to achieve the communicative functions of the text (Kress \&van Leeuwen, 1996). There are five different types of modes as semiotic systems: linguistic, visual, aural, gestural and spatial. The texts in social media include many signs such as letters, words, drawings, pictures, videos, music, facial gestures, and design of space. Most of the texts in social media can be considered as multimodal texts as they combine modes such as visuals, audio and linguistic texts. Therefore, based on this, the current study focuses on perspectives on family relationships as expressed in multimodal texts in social media during the Covid 19 containment period.

The multimodal tools used in this paper are printed written texts, images and videos. These different modes that design multimodal texts shape the people's society on family relationships. Semiotics on the other hand is the study of sign system. It explores how words and other signs make meaning. In semiotics, a sign is anything that stands for something other than itself. This paper focuses on both the linguistic, audio and visual signs. There are three major theoretical bases in use in multimodal Discourse Analysis. Firstly, Hallidayan Systemic Functional Linguistics underpinning a social semiotic and SFL approach (Halliday,1985,1978) Secondly, the Mediated Discourse Analysis underpinning a mediated action-based approach. Thirdly, Conversational Analysis (CA) underpinning a turntaking approach. This paper will analyses texts from the three theoretical bases. In Systemic Functional Grammar (SFG), "Language is interpreted as a system of meanings accompanied by forms through which the meanings can be realized" Thus SFG focuses on the means of realizing the functions of language (Lirola, 2006). According to Halliday's framework, in language structure and human communication, there are three meta-functions namely; ideational, interpersonal and textual functions (Halliday,1985,1978). This paper utilizes the three metafunctions of language in the analysis and interpretation of the Covid 19 social media discourses on family relationships.

\section{MATERIALS AND METHODOLOGY}

The purpose of this study is to analyse how multimodal discourses of the Covid 19 containment social media discourses in Kenya interact and exert the effects on perspectives on family relationships. Thus, the study attempts to provide an answer to the following questions.

Q1: How is the interactive meaning constructed in linguistic mode?

Q2: How is interactive meaning facilitated in visual mode?

Q3: How are the linguistic and visual modes combined to construct the interactive meaning?

In terms of data collection, theoretical sampling was used and twenty-eight (28) Covid 19 containment social media discourses were sampled for analysis. The texts for analysis were chosen from the internet by browsing through whasup groups. Permission was also sought from Whasup groups administrators for purposes of accessing and using the texts. The study analysed linguistic and visual messages in Covid 19 containment discourses in social media respectively and then study the interaction relations on family perspectives. Family perspectives in this case relate to issues of relationship between couples, attitude, perception on marriage, relationship between parents and children (parenting, values, virtues,), family traditions and customs, family finances, fear, family providence, safety, dominance, domestic violence, family unity, gendered families. 


\section{RESULTS AND DISCUSSION}

\subsection{Interactive Meaning in the Linguistic and Visual Modes}

The first and second research questions were concerned with how the interactive meaning is constructed in the linguistic mode.

\subsubsection{POVERTY CHALLENGES}

The social media discourses exposed the challenge of poverty among families. Poverty comes with its own challenges too as most families which live below a dollar a day are faced with the dilemma of either attending to their small-scale businesses as usual and risk dying from the corona disease or staying at home and die of hunger. Therefore, the poor man faces the challenge of diseases and hunger. These challenges often lead to idleness, harassment, and finally domestic violence as it will be demonstrated in this paper.

i) Dilemma in families

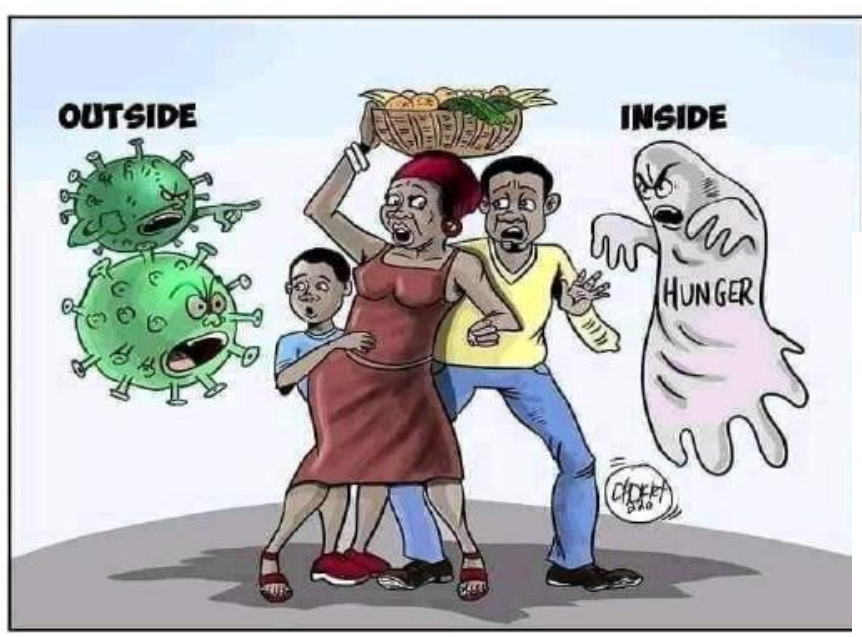

Sample 1

\section{Sample 1}

Sample 1 depicts a context of two environments facing the family. On one side is the corona virus from the outside (work, market, school etc.) and hunger from the inside(family).

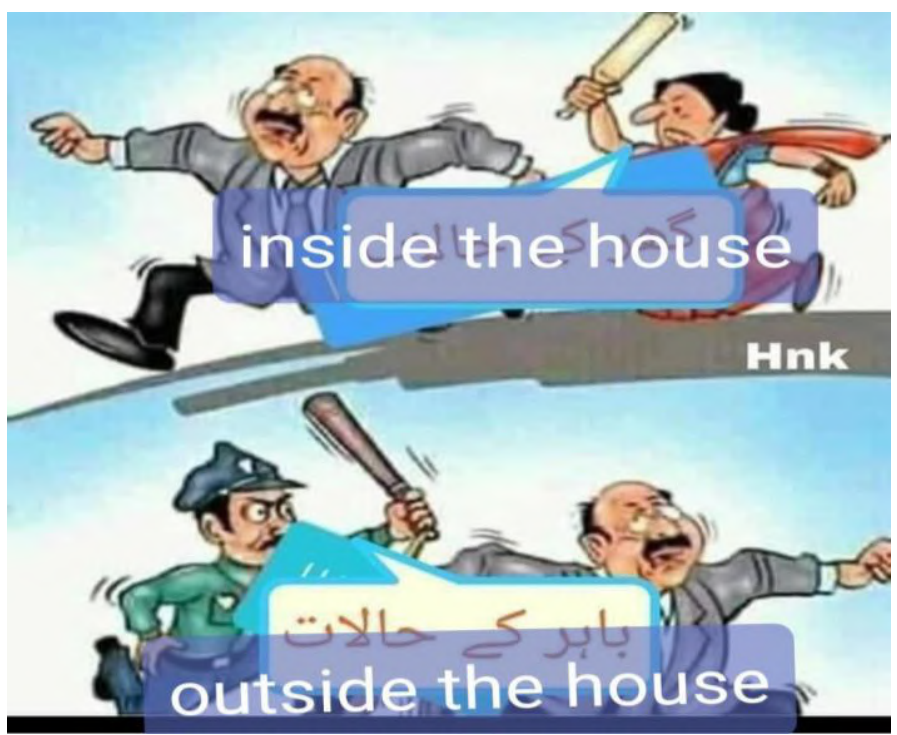

Sample 2

Sample 2 portrays a dilemma where that brings in police harassment from the outside(society) and wife harassment from the inside(family). The act of the police officers beating citizens was occasioned by the refusal of some citizens to obey the curfew hours and stay at home order in some countries such as Kenya and Malawi. This action further reveals gaps in the rule of the law in such countries.

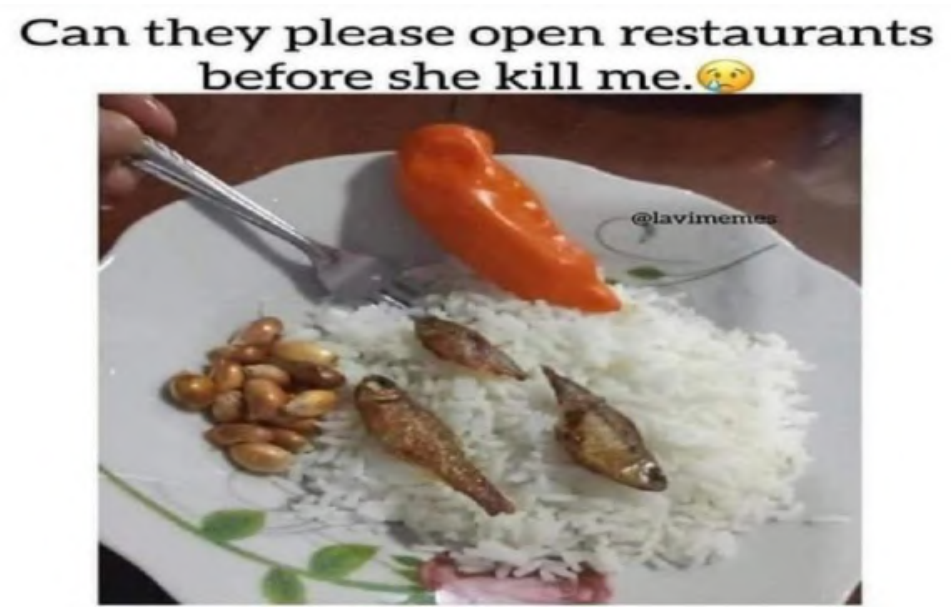

Sample 3

On the other hand, the harassment by the wife could be occasioned by many factors such as lack of food which the husband has to provide or other family challenges such as idleness. This situation leaves the man in a dilemma on where to run to and occasionally, this may result in domestic violence as illustrated in Sample 3. The husband laments that if hotels are not opened, he will die of hunger because the wife serves him very little food. 


\section{Married men right now at home.}

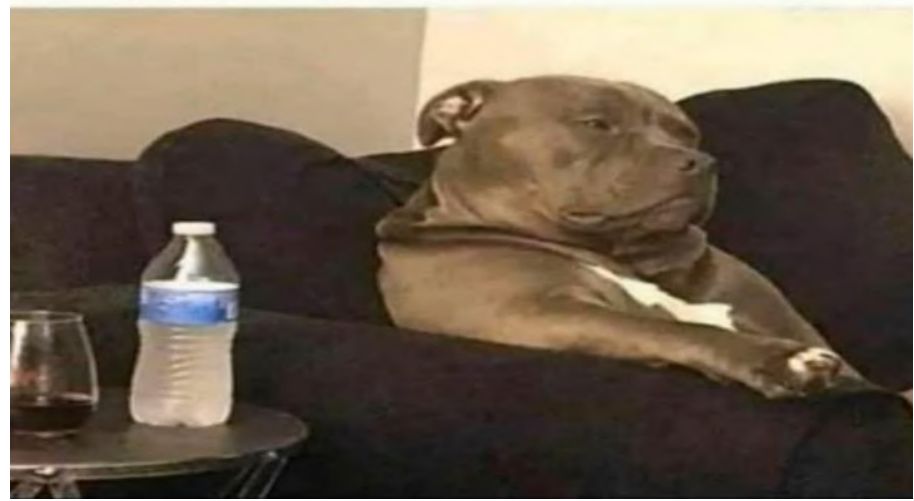

Sample 4

Consequently, in Sample 4, the man is left sad, hungry, lonely and bitter as demonstrated in 4 . The family is faced with two life threatening challenges which leave it in a catch 22 situation. Either of the choices will threaten the existence of the family. This caption captures the dilemma in which most families are undergoing during the Covid 19 period. It also depicts the challenges that families face, hunger, diseases which always cause fear and panic. The facial expressions and body gestures of the persons in the caption indicate fear. The family is living in fear of diseases and hunger which is a face value of poverty. It is important to observe that most families in Africa, live below a dollar a day. Their means of survival if from hand to mouth. Therefore, a lockdown implies is tantamount to death just as the Covid 19 itself.

\subsubsection{RELATIONSHIP BETWEEN COUPLES}

The multimodal discourses have also revealed that couples face numerous challenges and among them phone related challenges, desire for polygamy, procreation, domestic violence, mistrust, and loneliness, discontentment among others.

The following is a demonstration of some of these challenges.

i) Phone related issues
I will never drink at home again.. last night I almost gave my phone to my wife telling her.... "Save your phone Number I will call you tomorrow"

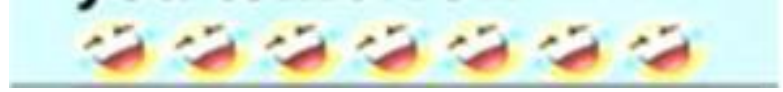

Sample 5



Sample 6

Sample 5 is a linguistic text that reveals the relationship between family couples. The context of the text is a husband who gets drunk at home and while in the house, he forgets and almost gives his phone to his wife (thinking it is a bar maid) to save her phone number for future engagement. This text reveals the underlying meaning of adultery on the part of the husband and fear of the wife. The emojis also show how cunning the husband comes out of the almost would be tragic situation. This text is a reflection of mistrust and fear that exist among couples. There is a common tendency of women snooping on their husband too. The wife mistrusts the husband as concerns his conversations over the phone. On the other hand, the underlying implication of the mistrust is that the husband could be cheating on her too. The idea that the couples snoop on each other is a show of lack of 
openness and trust between coups which is a recipe for broken marriages.

The issue of suspected men cheating on their wives is also demonstrated in sample $2 b$ where a neighbor observes that during the Covid 19 lockdown, most men make their phone calls outside the gate. This scenario makes one wonder why a person should leave his house only to take a phone call from the gate. This action creates suspicion. Other phone related challenges are evidenced in the contexts where a woman advise fellow women to follow men whenever they go out to receive phone calls instead just snooping on them, "If his phone rings and he goes outside, my sister, follow him. Don't be lazy. Help him find network." (Sample 7) This is an emancipatory and empowerment call for women to keep a check on husbands who appear to cheat on them. This phone discourse reveals a challenge of unfaithfulness in marriages. The Covid 19 lockdown brings out this perspective.

\section{Sample 6}

Quarantine Diaries is a text in a diary format which details the events of a mother and child in the absence of the father. The events take place for a considerable period of time. The entries reveal that the wife is involved in an extramarital affair in the absence of the husband. The husband snoops on his wife by use of their daughter who reveals everything that the mother does to him.

*Quarantine Diaries*

*Day $1 *$

Wife: Tilly come take ur breakfast it's getting cold.

Tilly: I wanna take it with dad together on the dinning table.

Dad: Tilly baby, I'll soon join $u$ dear, go start it.

Tilly: okay daddy.

Dad joins Tilly no sooner after she got to the table.

Tilly: Dad, my tea is too hot.

Dad: Sorry dear, let me cool it down a little for $u$.

Wife joins from the kitchen.
Wife goes to the kitchen to pick something.

Tilly: I love u dad, $u$ are not like the uncle who comes here when $u$ go to work. He does not eat on the dinning table; he eats with mum in your room.

Dad in shock, stops taking the breakfast and sighs.

Wife: Honey $u$ ain't eating your food, are u $O K$ ?

Why the sudden mood swing?

Dad: I'm good dear I just lost appetite.

$\cdots$

Later that evening, Dad was watching TV in the hall.

Tilly runs to him.

Dad: Tilly baby, have u taken your bath already.

Tilly : Yes daddy.

Dad: good girl. So tell me, do u know the uncle who comes where any time I go to work?

Tilly: Yes daddy, one day he left something on the table so I took it and use it to play, it's in my school bag.

Dad: Go and bring it.

( Tilly brings a voters $\mathbb{1 0}$ that fell from the said Uncle's wallet)

Tilly: This is it dad.

Dad: Good girl, is that the only thing he left here?

Tilly: yes dad

Mum walks in from the bedroom.

ISSN: 2456-7620 
Mum: Daddy and daughter, what are $u$ guys discussing.

Dad: Quickly he replied, we are watching movie and discussing it.

*Day $2 *$

Dad woke up from bed but didn't give wife the usual good morning peck on her forehead.

Wife: honey, my good morning kiss $\bigodot$

...Dad: smiles, picks up Tilly and taps her at the back, saying I'm fine my dear. I don't need a doctor $O K$.

Tilly: OK daddy then smiles for me (-)

Dad: 20.

Wife gets closer and joins the conversation.

Wife and Dad begins conversation.

Wife: Honey, I've realised uv Bern behaving weird since yesterday after $u$ abandoned my food on the dining table.

What's the problem?

Have I done anything wrong.

Dad: Hmmmm, I'm sorry dear. It's just about the lockdown and how I've been idle doing nothing. It's getting me boring.

Wife : Is that enough reason to abandon my food? Honey the lock down is affecting us all but $u$ shouldn't make me feel I caused it by abandoning my food and acting weird towards me.

$U$ refused me of the usual good morning peck on bed this morning, what about that?

Dad: I'm sorry love. It won't happen again.

...

Later that day, mum was in the kitchen, her phone was on charge in the hall then a text came in.

It reads *" hello baby, I know he was around that's why $u$ couldn't speak to me, I'm sure he has always been around $u$ that's why we can't talk, but I still think about $u$ all night. Our last meeting was a blast. How I wish this pandemic is over so $u$ ride me again like a polo horse -2. Take care baby, and don't let him enjoy it all alone it's mine too bye'*

Dad: takes a shot of it with phone and sits to watch $T V$.

Tilly goes to the kitchen.

Wife: where is dad

Tilly: He is watching TV in the hall.

Wife: Go get me my phone dear, it's on charge in the hall.

Tilly brought the phone and mum saw the text.

After meals.

Dad: Honey, have I done anything wrong that $u$ didn't tell me?

Wife: No honey. 
Dad: Are u sure? I wanna apologize if I have.

...

Moments later dad went out to have some fresh air outside.

Wife makes call with the number that texted her in the noon. Tilly hears part of it and goes out to ask the meaning of statement from dad.

Tilly: Dad, what is the meaning of banging, and I lost my period?

Dad: Shocked, where did $u$ hear those words?

Tilly: Mum was telling someone on her phone so I want to know the meaning.

Dad: They mean nothing my dear, they are words $u$ will understand when u grow okay??

Tilly: Okay daddy.

The quarantine diaries reveal a family environment full of snooping, mistrust and cheating spouses. It also reveals the extent to which absentee partners use their children to snoop on their spouses which is a recipe for future kids who are snoopers too. in addition, the extent of cheating is accelerated by the fact that spouses stay away from each other for quite some time and this brings about loneliness, boredom hence cheating. The worst scenario in marriages that this sample reveals is that extra marital affairs result in children out of wedlock hence future demonstration of breaking marriages.

ii) Desire for Polygamy

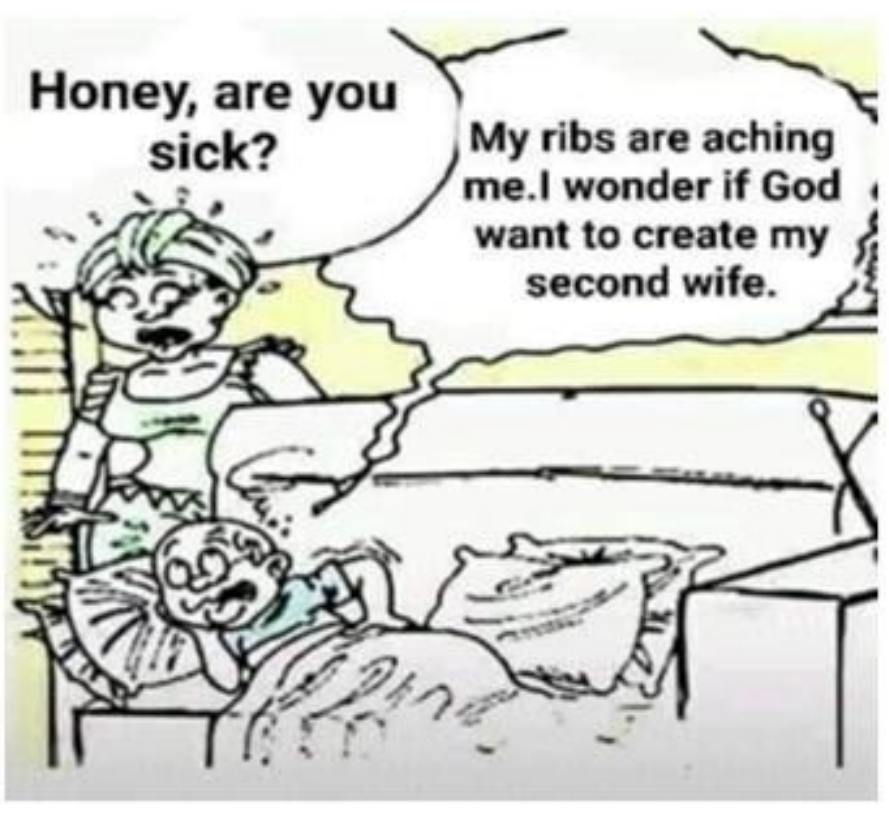

Sample 8

Sample 8 is a context involving a husband and a wife, the husband is in bed and when the wife checks on him, he says that his ribs are aching and he wonders whether God wants to create a second wife for him. This is so humorous but at the same time sarcastic. The husband alludes to the Bible story that God created woman, a helper from Adam's rib when he fell asleep. The import of this allusion is that the husband wants to marry another wife. These news surprises the first wife as seen from the facial expression. The choice of the words "honey" by the wife are a sign of care and love. However, the sarcastic facial expression with the verbal utterances of the sleeping husband communicates the subtle message of his intention to get another wife.

The response from the husband on his intention to marry a second wife shows a strained relationship between the husband and the wife. The underlying reasons could be subtle and the Covid 19 period may have escalated the issues. This points towards challenges in families which might consequently break during the lockdown. The husband uses the religion to justify his intention to get another wife. The stay at home order might have caused boredom, intolerance, dominance, which could have contributed to breaking of families.

iii) Domestic Violence 


\section{Day 7 of the quarantine My wife took up gardening but won't tell what she's going to plant}

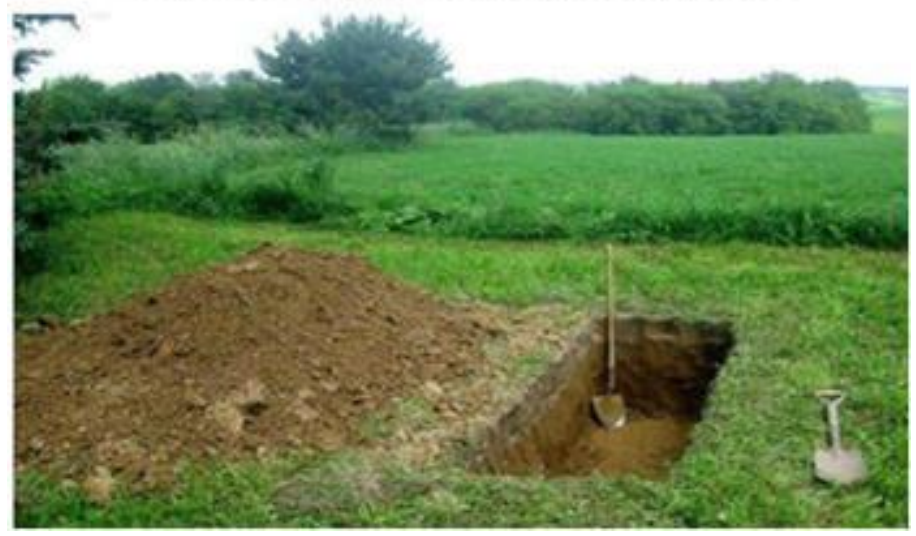

Sample 9

Sample 9 opens into a context of a seven (7) day quarantine at home. The speaker is a husband who claims that his wife took up gardening but she never told him what she was going to plant. This shows that the wife was never a gardener in the first place but took up the activity during the quarantine period. The choice of the husband's words points to something sinister or suspicious about the wives gardening activities. The visual text shows the gardening activity of the wife- a grave! This begs the question of who had died and was to be buried in this grave. Our common interpretation is that most likely, the body would be that of the husband or both. This act of a grave and the main agents in the text being couples is an indicator of domestic violence which might turn tragic. The context constructs marriage as a breaking unit during the Covid 19 quarantine. It points towards the challenges that couples face which were accelerated during the quarantine period.

It also challenges the dominance of men in the household. Naturally, women rarely dig graves for the dead. Grave digging is the work of men. The fact that the wife who secretly digs a grave, and alone, constructs her as a very strong, energetic person. Further, the fact that she digs the grave, a man's work, indicates how power is played in the interaction. The grave digging action and the intent of killing the husband constructs the wife as wielding more power than the husband. This points towards gender violence against men in the families. Domestic violence is also demonstrated in most of the images in which a fight ensues between the husband and the wife. Consequently, the wife overpowers the husband who clutches his bag and runs for his life. The video has a caption in slang Kiswahili which says., "Alafu unasikia tukiabiwa(sic) 2kae nyumbani”. This which literarily translates in English as "then you hear them tell us to stay at home". The fact that the post is from majority of the men, it shows how married men live in fear of their wives back at home. According to them, they are better of and safe at their work place.

iv) Idleness

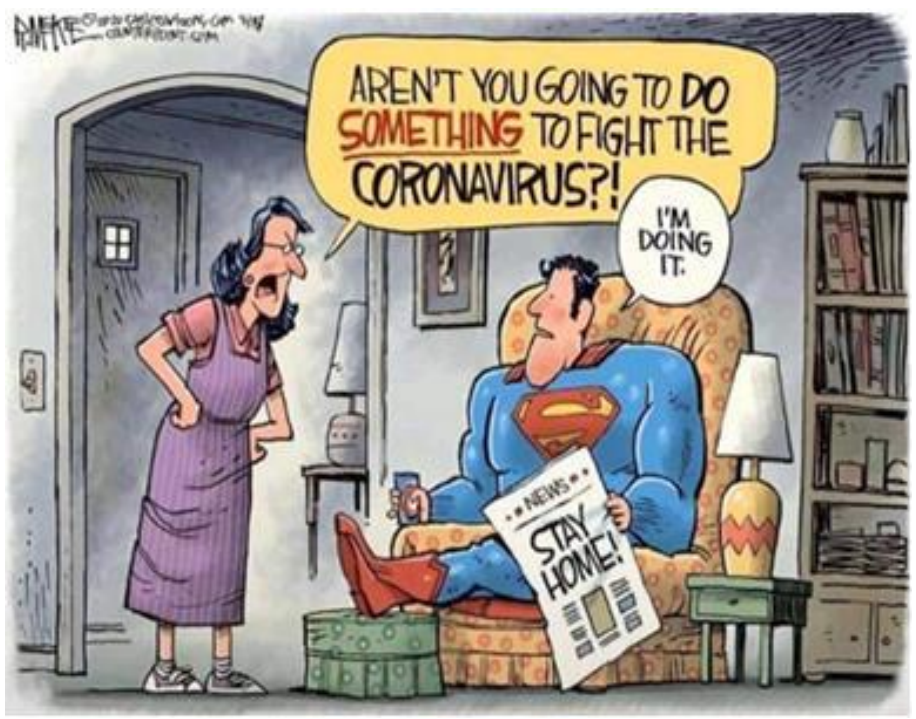

Sample 10

Sample 10 is a context in a home during the quarantine period. The caption shows a husband seated in the living room on a coach reading a newspaper. The wife supposedly, comes in and asks him to do something about fighting Covid 19 pandemic. The husband responds that he is already doing it-staying at home. The question from the wife is vague and the husband takes advantage of the vagueness to respond literally that he was fighting the Covid pandemic by staying safe at home. The implied meaning from the wife's question was challenging the might be idle habit of the husband. Doing something at home to fight Covid is subject to different interpretations-either the wife is tired of the husbands' idleness or improvidence. The wife's facial expression shows anguish and could suggest a quarrel or a fight. She appears to be yelling at the husband which is an indicator of verbal violence and intolerance. On the other hand, the husband appears to have a well-built physique yet what he does from the wife's choice of words is idleness. This shows the negligence of family responsibilities on his part and this might be the cause of verbal assault from the wife. 
v) Family power relations/struggle

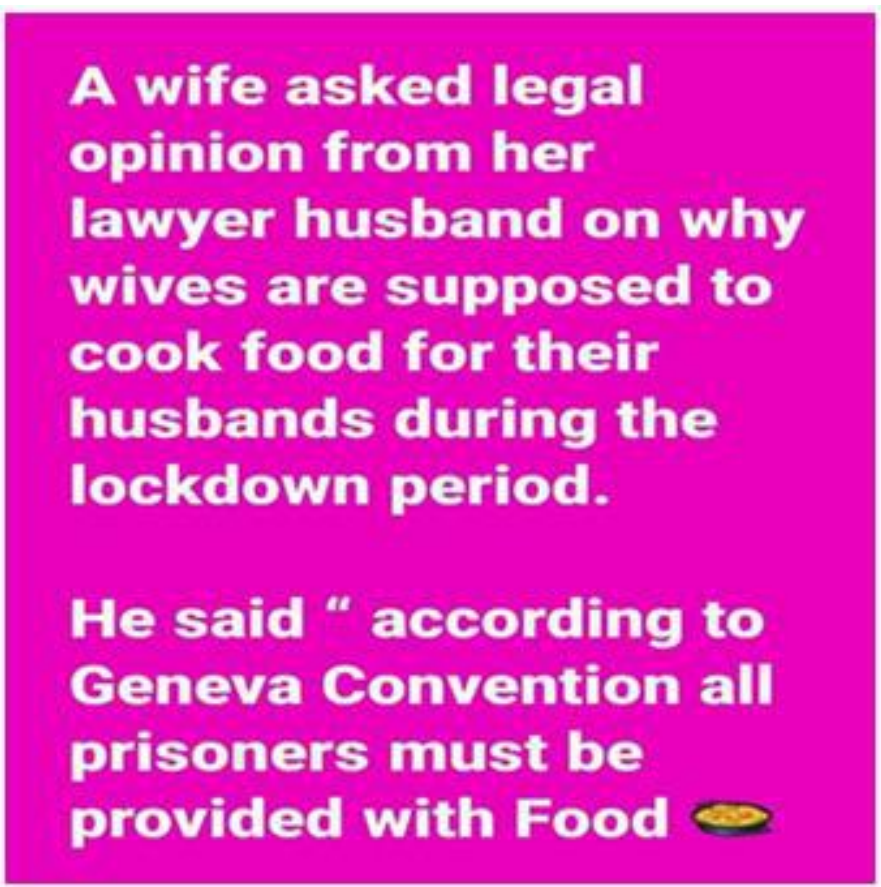

Sample 11

Sample 11 depicts a context where a couple is having a conversation about cooking. A wife asks her husband the reason why wives have to prepare food for their husbands during the lockdown period. The response from the husband is that wives are obliged to cook for their husband during the lockdown because husbands are prisoners who have to be provided with food. In some settings, particularly in Africa, it is the duty of wives to cook for their husbands whether in lockdown or not. Cooking is one of the domestic chores for women. However, in this caption, there is an implication that wives no longer cook for their husbands but only during such times as the Covid 19 situation. Despite this, the wives still are not comfortable cooking for their husbands. This implies a shift in power pointing towards equality and sharing of domestic chores. The women so far are challenging the men to take up the domestic chores just like any other role. This shift is an indicator of emancipation of women.

The response from the husband that husbands have to be cooked for because they are prisoners constructs an image of men living as prisoners in their own homes/. A prisoner is a person who has no freedom whatsoever, and he has lost his identity. A prisoner has no voice only to obey rules. the only freedom a prisoner has is being provided with food after hard labour. This image of a prisoner is an indicator of imbalanced power relations at the family level. The husband being a prisoner shows that he is at the mercy of the wife. This implies a shift in dominance. The import of this caption is that families experience power struggle relations which often result in domestic violence hence threaten the sustainability and survival of the very marriage. Based on this, the Covid 19 lockdown may result in family breakages.

vi) Fear

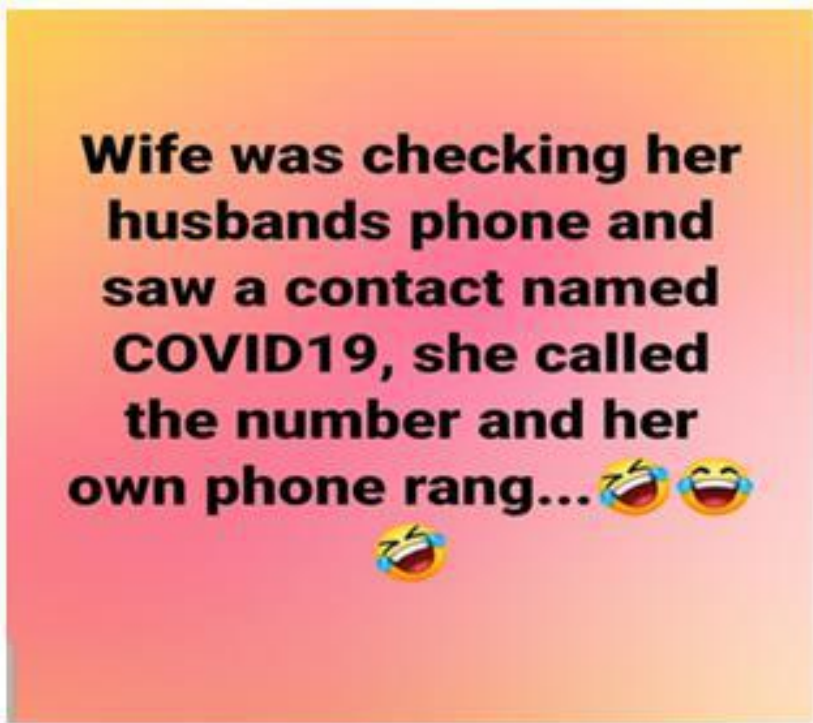

Sample 12

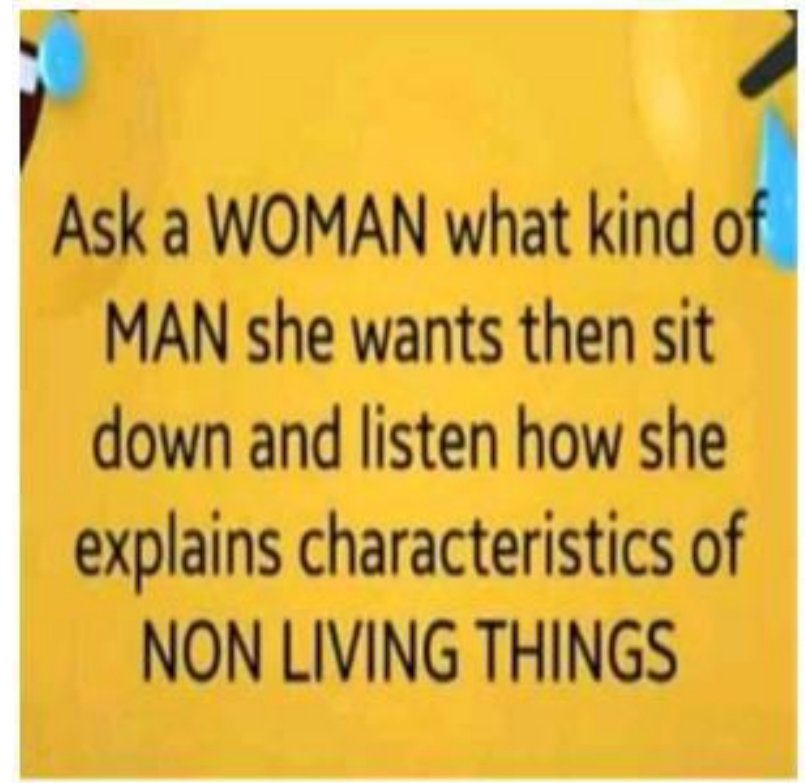

Sample 13

Sample 13 depicts a context where a wife is at home and she was snooping on her husbands' phone. She comes across a contact saved as Covid 19, she calls the number and 
her own phone rang. The fact that the wife snoops on her husbands' phone is a culture of mistrust that exists in marriages. On the other hand, the act of saving the wife's contact as Covid 19 is an indicator of a horrible person. This is because Covid 19 is a disease that spreads very fast and can kill within a very short time. It is a scaring disease. The import of these attributes constructs the wife as a very horrible, scaring person. The caption therefore captures a situation of mistrust and terrible fear that exists between couples. This caption was commonly posted by men in the whasup social media and thus the laughing emojis show that the men are sarcastically laughing at wives for being likened to Covid 19. This imagery is a very horrible construction of wives by husbands.

Sample 14 is a context of marriage where a woman has to make recommendations on the type of man he would want to marry. Surprisingly, the woman explains the characteristics using non-living things. This imagery indicates that in the perception of women, men are not human. They do not exist.

vii) Sex and child bearing

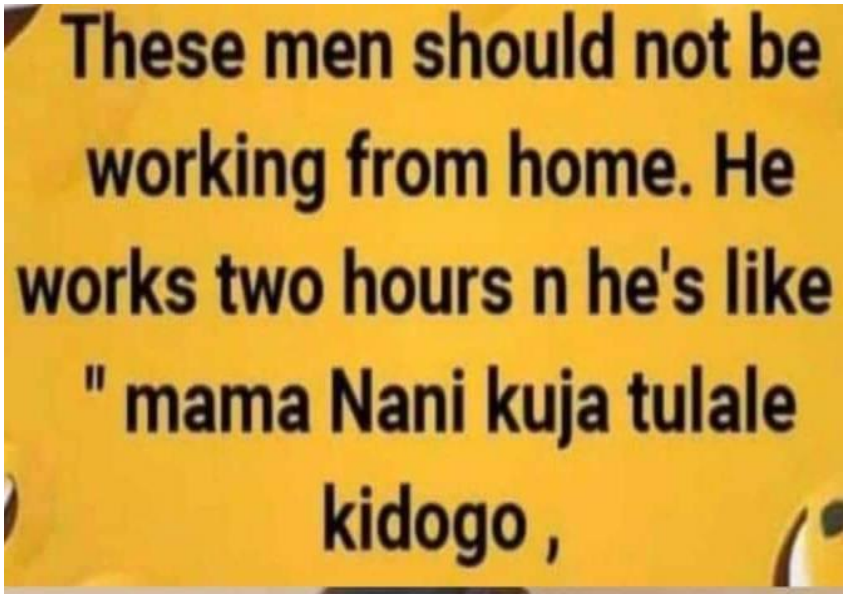

Sample 15

Sample 15 expresses a setting of a Covid 19 lockdown where couples are at home. The lockdown meant that people had to work from home. in literal translation, this caption posted by women mainly, a wife is lamenting that men should never work from home because hardly two hours, they call the wife to sleep a bit. In an African setting, sleeping is a euphemistic word meaning to make love. The facial expression and the gesture from the woman in the caption show a feeling of tiredness and being fed up and disgust.
Family reunions is supposed to be a joyful experience but this is not what is presented in this caption. The import of this caption is that the Covid 19 stay at home measures burdened the wives in terms of the conjugal rights. The begging question is why this should be the case? This could be as a result of idle men and maybe also the men who had never had a chance of staying with their families and enjoy such rights now have the opportunity. The fact that the wife is disgusted and not interested in sex could be an indicator of denial of family conjugal rights which is a pointer to other underlying challenges such as unfaithfulness or power play. This can be construed as a major paradigm shift where women are no longer used as sex objects by men rather the men have to meet and fulfil their family responsibilities first. The other possible implication of this caption could be that the wife is scared of getting pregnant and that is why she is reluctant to give in all the time. As mentioned earlier, most Africans live below a dollar per day and any increase in the number of children is a recipe for more poverty.

\section{Go to the kitchen. Tell your mother that you want a brother to play with}

Sample 16

Sample 16 expresses a situation where a husband is afraid of asking for conjugal rights from his wife and so he uses his son to inform his mother that he needs a brother to play with. In as much as in 15 , the wives are tired of having sex with their husbands, in 16 , the husbands not only want sex but also more children. Sample 15 and 16 point towards intimate partner violence which has been spiked by the Covid 19 lockdown.

THERE ARE ONLY 3 WAYS TO COME OUT OF THIS LOCK DOWN?

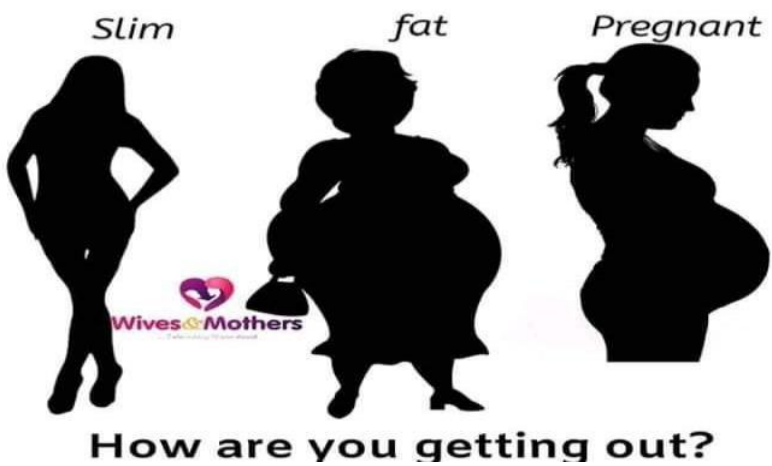

Sample 17 
Sample 17 contextualizes a situation of dilemma oh how the Covid 19 lockdown would come to an end. Women seem to warry about their stay at home because they are not sure whether they will emerge pregnant, fat or fit.

On the overall, Samples 15-17 on the overall portrays a situation of fear and worry about sex and child bearing among women. Women appear to be very cautious on matters of child bearing. This could point out on the major challenge of child upbringing amidst challenges of poverty. Further, the social distancing aspect as alluded in the following sample $9 \mathrm{c}$ shows that couples took advantage of the same regulation to distance themselves from their matrimonial beds. This illustrates challenges among couples.

\section{Sample 18}

*"Latest lockdown breaking news"*

No birth certificate will be issued by

the Govt. for children born between

*Jan. 2021 to Feb. 2021...*

*REASON: Did not maintain social distance

during

Lockdown*(-)(-)(-):

The above Sample 18 crowns the effect of the lockdown on the couples especially when it comes to conjugal rights.

viii) Irony of life in marriage

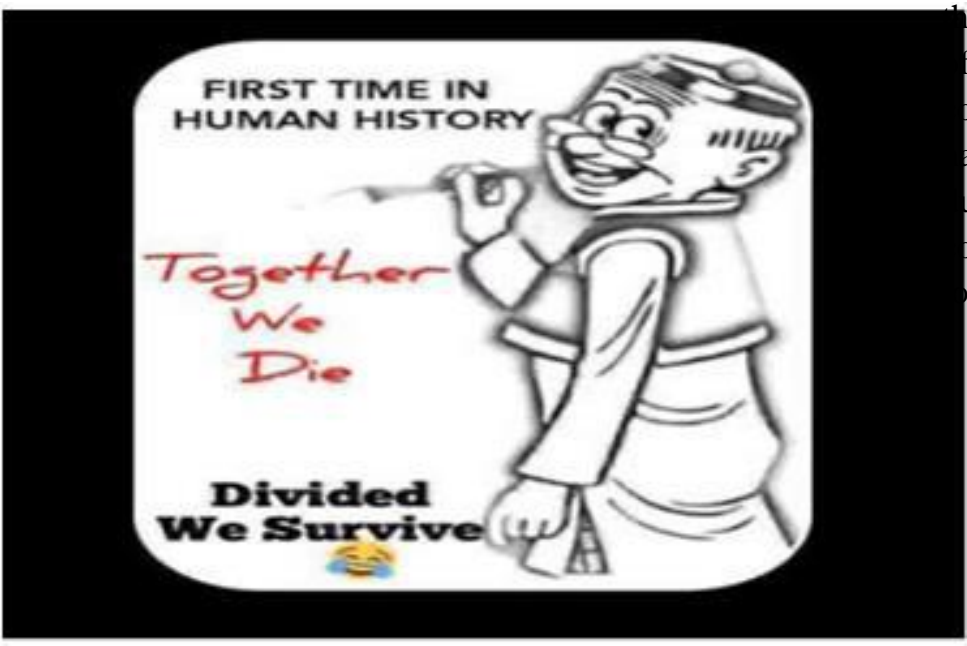

Sample 19

Sample 19 is a poster which shows the happiness from the woman given that in the history of human beings the corona virus has demonstrated that social distancing is the only way to curb the spreading of the deadly virus. The woman caricature is smiling as she indicates that social distancing is important. This begs the question as to whether social distancing among couples who are not infected is a good idea. This is contrary to what appears to be the joy of most couples as depicted in the caption. Why is this the case then? The couples seem to celebrate social distancing which is an indicator of unwillingness to stay together. This may imply that families are on the verge of collapsing because couples tolerate each other instead of loving each other and enjoying the unity.

ix) Boredom in marriage

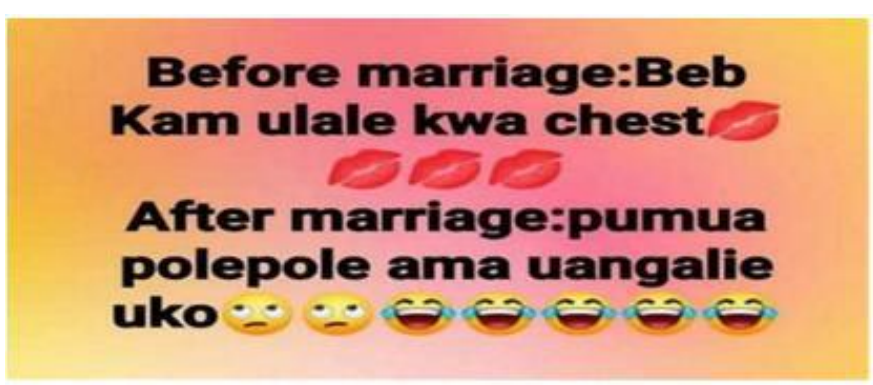

\section{Sample 20}

Sample 20 depicts a setting of the aftermath of marriage where love has fizzled away and what is remaining is resentment. The choice of the words in the text before marriage are loving words. A husband welcomes the wife to sleep near his chest as a sign of love. Even the emojis used depict love. However, after marriage, the choice of words by e husband depicts resentment. The husband is already tired the wife and does not want her to sleep close to him. This mparison of love in marriage shows that most marriages ardly stand the test of time. The fact that this text is posted uring the Covid 19 stay at home order may imply that most puples find it hard to cope with each other which may lead family breakages.

\section{x) Harassment}

Sample 21 juxtaposes two scenarios facing married men during the lockdown, the first one is being in the lockdown with money. This situation is more of isolation according to the men because they will be able to fend for their families. isolation is a little bit friendly because men can access some love and food from the wife. The second scenario however, portrays a different picture that portends harassment. for men, being at home without money and with a quarrelsome wife is like hell on earth. This indicates that money defines a marriage and without such, the marriage becomes a total lockdown for husbands. Total lockdown entails lack of total freedom hence harassment/ violence against men. 


\section{Know the Difference:}

If you're staying at

home with money, you're in isolation.

If you're staying at home, broke, you're in quarantine.

But if you're staying at home, broke and with a troublesome wife, you're in total lockdown!

Sample 21

\subsubsection{FAMILY RELATIONSHIPS WITH CHILDREN}

The Covid 19 lockdown also brought on board the relationship between parents and their children. most parents were faced with the challenge of parenting which was complicated by the lockdown given that schools closed and children were at home with parents for a longer than expected period of time. some of the issues that the social media discourses revealed included loitering, disobedience, teen relationships, parenting, etc.

xi) Family Re-union

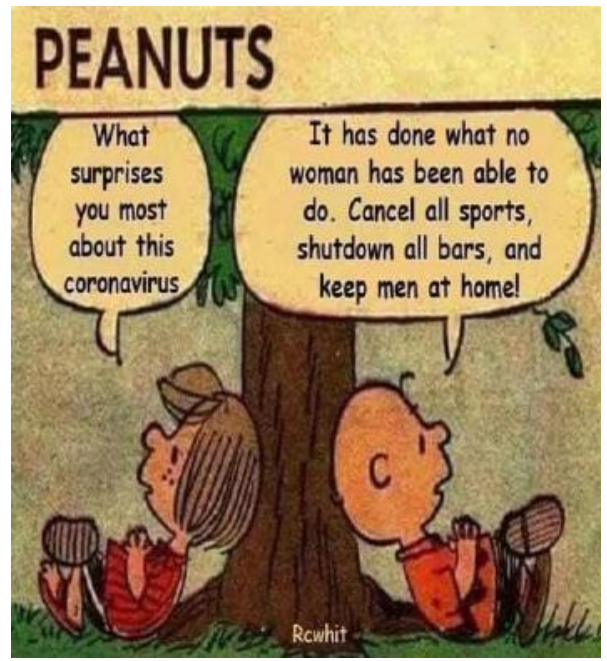

Sample 22

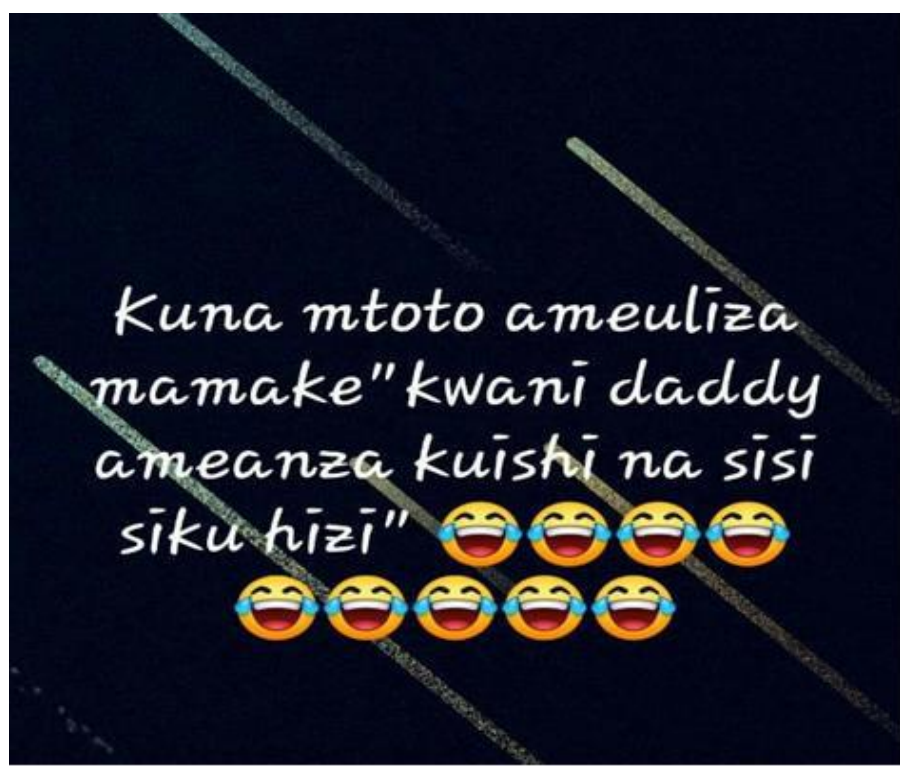

Sample 23

Sample 22-23 is a setting with the children's voice on their parents. The children have on a conversation about the stay at home order due to the Corona virus. They are surprised that during the period the fathers are now available at home because there no more sports and bars. From the children's sentiments, it is clear that women had tried to keep men at home but thanks to Covid 19, it has done it all for them. This caption brings on board the idea of missing fathers at home hence an impact on parenting. The children see the Covid 19 as a blessing because they can now have valuable time with their fathers. It is also evident that men spend most of their time on sports and at bars. This observation from a child's perspective is rather a negative character which constructs fathers as careless, irresponsible and unavailable hence poor parenting. The caption presents children relaxing under a tree which is an indicator of the goodness the Corona virus has brought- bringing their fathers home and thus uniting the family again and they can now feel safe. This sample reveals absentee fathers hence the burden of parenting is left for the mothers.

xii) Role Modelling on kinship issues

Kinship Issue 


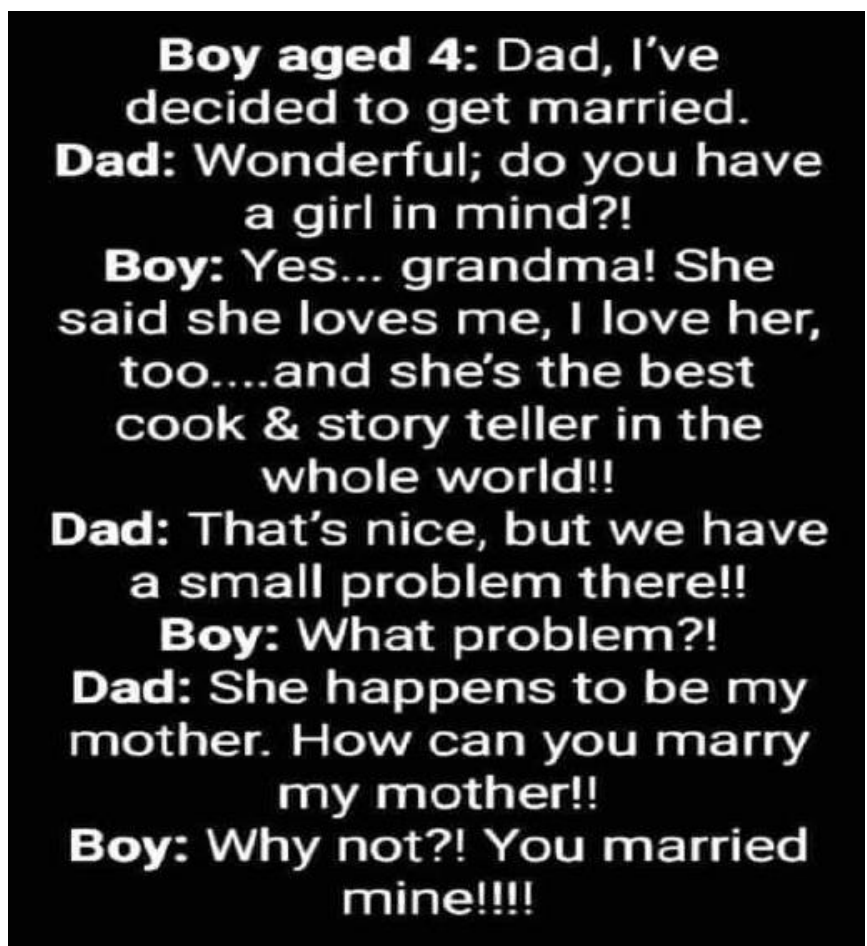

Sample 24

Sample 24 contextualises a parenting process. a boy aged 4 years only talks about marriage and he wants to marry his grandmother because his father married his mother. this scenario portrays a gap in parenting on matters of kinship. This is a wake-up call to fathers to take up the role of educating their children about marriage and kinship,

Leadership matters
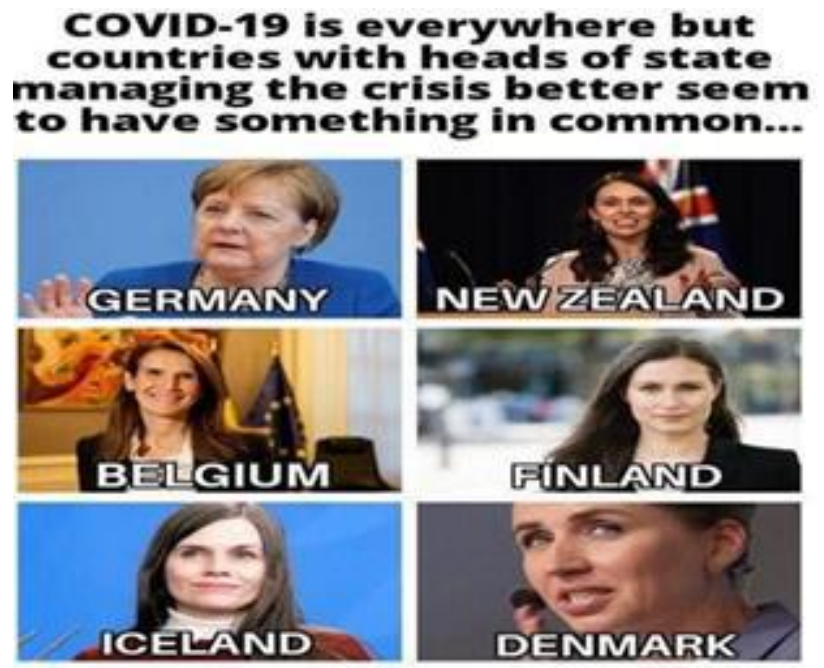

Sample 25

Sample 25. depicts a scenario of gender undertones projection a perception that women leaders are better leaders than men because they have been able to combat Covid 19 compared to their male counterparts. in 26 , this is the very reason why in 25 , the successful leaders are women as opposed to men.

Sample 26:

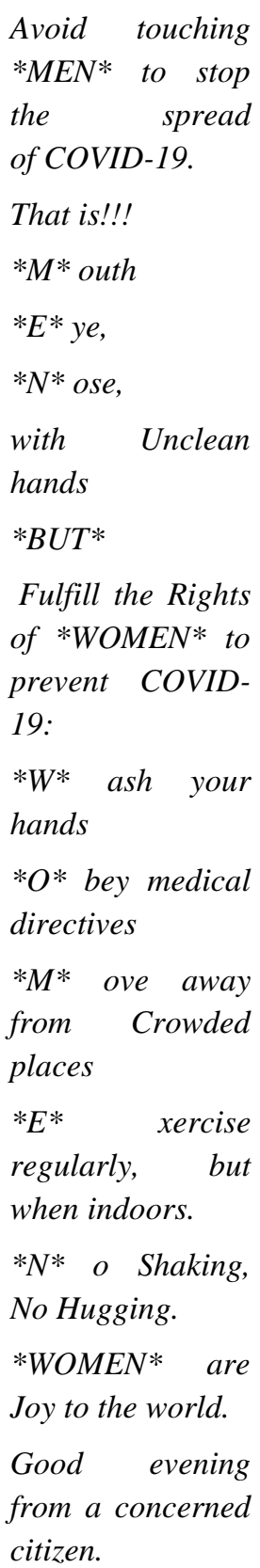

In Sample 26, gender disparity is equally evident where men are treated as villains and women as heroes. The same narrative is advanced in the following sample 27:

Sample 27

४... * Queen Elizabeth $I I^{*} G B$ 
Has survived.....

The plague

Smallpox

Malaria

WWII

Korean War

Vietnam War

Making of Land Rover and Range

Rover

The Concord

The retirement of the Concord

Nazi rule in Germany

Destruction of Berlin

Partition of Berlin

Unifications of Berlin

Creation of Israel

Sending poor Palestinians into diaspora

Tripartite invasion of Egypt in 1956

1967 Arab-Israeli War

October 1973 War

West-East Cold War

Iran-Iraq War

First Gulf War

Fall of Saddam Hussein

Fall and disintegration of Soviet

Union

Britain joining the $E U$

Britain leaving the $E U$

Apollo 1-17

Independence of countries in Asia and Africa

14 British Prime Ministers

Charles and Diana

Charles and Camilla

Andrew and Fergie

Harry and Megan

14 American Presidents
7 Saudi Kings

48 Italian Prime Ministers

9 UN Secretary-Generals

3rd, 4th, and 5th French Republics

Mad Cow Disease

The Internet

Apple TV

Netflix

Wi-Fi

Covid

She keeps wearing gloves $\square$ in public

But most of all... she rarely leaves her palace......

*So, Stay at Home....*

Sample 27 glorifies women's biological immunity with the illustration of Queen Elizabeth II who has conquered so many pandemics. The import of this illustration is that men are weak whereas women are strong naturally. This equally brings out gender parity issues.

xv) Family finances/ expenditure

\section{Sample 28}

*Quarantine effect on Auditors at home during Corona lockdown**

Auditors have realised that home \& kitchen are the most mismanaged places -

*Following anomalies/Queries have been found:, *

1. There is no stock ledger maintained. Procurement is not in line with provision factor. Purchase orders are placed verbally. Inventory maintenance is very poor.

2. There are no budgeting documents

3. There is no indexing of products

4. No bin cards were displayed

5. No Annual, monthly or quarterly stock taking has been carried out 


\begin{abstract}
6. No Inspection has been carried out for years. Most of the spoons and plates are of wrong pattern and do not match with the original part number
\end{abstract}

7. No balance sheet and Profit \& Loss statement ever prepared

8. Weighing scales non existence

9. No handing over /taking over files maintained

\section{No SOP and menu displayed}

\section{No firefighting equipment}

12. Sufficient reserves are not
maintained

Sample 28 indicates a situation of financial mismanagement at home and specifically in the kitchen. This illustrates that since the kitchen is the centre of women chores, by extension, women are poor finance managers. The caption indicates that no inspection has been done for years, meaning that the lockdown has provided an opportunity for men to get into the picture of how money is managed at home. The realization is that their wives have been mismanaging resources either by not buying what the money is intended for or wastage of what is available.

\subsection{Conclusion}

Social media interactions provide a platform where people share language on diverse subjects ranging from social, political or economic. This paper sought to analyse the interactive meaning constructed in linguistic mode, analyse how the interactive meaning facilitated in visual mode and lastly how the linguistic and visual modes combined to construct the interactive meaning. The findings confirm that social media brought on board some pertinent issues in regards to family relationships during the Covid 19 pandemic lockdown. The findings indicated that the Covid 19 lockdown revealed a strained relationship between couples, domestic violence and in this case, men were on the receiving end possibly for staying idle at home and being unable to provide for their families. There was also an indicator of constrained family finances, poverty, fear arising out of what the future holds for families in the midst of Covid 19 and lack of essential commodities for use. In addition, the findings showed cases of withdrawal of couples from their responsibilities, duties and roles among them, denial of conjugal rights and in this case, men were the victims, cases of spouse cheating, both male and female, spousal phone snooping, dominance and power struggle and here both men and women exercised power over each other, child bearing which most women declined through denial of conjugal rights and insinuations on polygamy. Further, it was established that children desired their fathers to be present in their lives. This pointed to the issue of absentee fathers. More so, parents were struggling with teenage relationships, virtues, values and morals. Finally, this paper concludes that families are gendered and even though these are only perspectives during the Covid 19 lockdown, the issues point to a larger picture of challenges which families experience on a daily basis hence the need for more intervention measures on the same.

\section{REFERENCES}

[1] Fairclough, N. (1989). Language and Power. Longman. New York.

[2] Fairclough, N. (1992), Discourse and Social Change. London. Polity press.

[3] Fairclough, N. (1995). Critical Discourse Analysis. London. Longman.

[4] Halloran, K, L. \& Smith, B, A (2010). Multi Modal Text Analysis, $\quad$ http://multimodal-analysislab.org/_docs/encyclopedia/01 Multimodal_Text_AnalysisO'Halloran_and_Smith.pdf accessed on 22/02/2018

[5] Halliday, M.A.K (1985). An Introduction to Grammar (First Edition). London: Edward Arnold.

[6] Halliday, M. A. K. (1978). Language as a Social Semiotic. The social interpretation of Language and Meaning. London: Edward Arnold.

[7] Janks. H. (1997). Critical Discourse Analysis as a Research Tool in Discourse. Studies in the Cultural Politics of Education 18(3):329-42

[8] Kress, G and Van Leeuwen, T (1996). Reading Images: The Grammar of Visual Design, London: Routledge Press.

[9] Licola, M. M. (2006). A Systemic Functional Analysis of Two Multimodal Covers. RevistaAlicantina de EstudiosIngeles. (19) 249-260

[10] Machin, D. (2007). Introduction to Multimodal Analysis. London: Hodder Arnold.

[11] Machin, D. \& Mayr, A. (2012). How To Do A Critical Discourse Analysis: A Multimodal Introduction. London. Sage.

[12] van Dijk. T. A. (2003). The discourse-knowledge interface. In: Weiss, G. and R. Wodak (eds.), Multidisciplinary CDA. (London, Longman), 85-109.

[13] Van Dijk. T. A. (1998a). Ideology. A multidisciplinary study. London: Sage. 
[14] United Nations, Economic and Social Council (UNESCO). Siracusa principles on the limitation and derogation provisions in the international covenant on civil and political rights, U.N. Doc. E/CN.4/1985/4, Annex (1985). United Nations; 1985 [Available from: http://hrlibrary.umn.edu/instree/siracusaprinciples.html.

[15] European Centre for Disease Prevention and Control. Novel coronavirus disease 2019 (COVID-19) pandemic: increased transmission in the EU/EEA and the UK - sixth update, 12 March 2020. Stockholm: ECDC; 2020

[16] WHO. Report of the WHO-China Joint Mission on Coronavirus Disease 2019 (COVID-19). Geneva: World Health Organization; 2020. 7.

[17] THE PANDEMIC OF SOCIAL MEDIA PANIC TRAVELS FASTER THAN THE COVID-19 OUTBREAK: Article (PDF Available) in Journal of Travel Medicine - March 2020 